\section{Low-temperature Storage of Garlic for Spring Planting}

\section{Gayle M. Volk ${ }^{1}$ and Kate E. Rotindo}

Plant Germplasm Preservation Research Unit, National Center for Genetic Resources Preservation, U.S. Department of Agriculture, Agricultural Research Service, Ft. Collins, CO 80521

Walter Lyons

Yucca Ridge Farm, Inc., 46050 Weld County Road 13, Ft. Collins, CO 80524

Additional index words. postharvest physiology, yield

Abstract. Garlic bulbs (Allium sativum $\mathrm{L}$.) harvested in the summer are often stored at room temperature between the time of harvest and curing and either consumption or planting in the fall. The quality of these bulbs usually deteriorates dramatically by 6 months after harvest. Garlic bulbs were placed at $-3,0$, or $5^{\circ} \mathrm{C}$ for $\approx 6$ months to determine if bulbs could be maintained for spring planting. Response to cold-storage conditions was cultivar dependent. We found that most cured garlic bulbs stored at $-3^{\circ} \mathrm{C}$ for 6 months successfully formed cloves within bulbs when planted in the following spring. Unlike the high-quality bulbs formed after $-3^{\circ} \mathrm{C}$ storage, bulbs stored at $0{ }^{\circ} \mathrm{C}$ for 6 months often formed side cloves and had loose wrappers. In another study, garlic bulbs stored at $0,5,15$, or $23^{\circ} \mathrm{C}$ exhibited a higher rate of shoot elongation within the cloves during storage than bulbs stored at $-3{ }^{\circ} \mathrm{C}$. After 9 months of $-3^{\circ} \mathrm{C}$ storage, bulbs then held at room temperature retained the quality characteristics of freshly harvested garlic (firmness, taste) for at least 2 months. These studies suggest that cured garlic can be spring planted and consumed year-round when bulbs are stored at $-3^{\circ} \mathrm{C}$

Most large-scale garlic (Allium sativum L.) producers grow 'California Early' and 'California Late' garlic bulbs for distribution to supermarkets and for use in the dehydration industry (Warade and Shinde 1998). There are more than 200 additional garlic cultivars grown on small farms throughout the United States that are usually sold within local fresh markets. Most of these cultivars are hardneck types (scape producing) and are genetically distinct from the 'California Early' and 'California Late' softneck garlic types (Pooler and Simon, 1993). Hardneck cultivars generally have shelf lives shorter than softneck cultivars (Rosen et al. 1999).

'California Early' and 'California Late' cultivars of garlic are often stored near $0{ }^{\circ} \mathrm{C}$ until they are distributed to the consumer (Chakraverty et al. 2003). Seed bulbs (cloves to be planted for the following season) are generally stored at ambient temperatures from harvest (June, July, or August, depending on location and cultivar) until planting in the fall. These storage practices are similar to those outlined in the revised USDA handbook The commercial storage of fruits, vegetables, and florist and nursery stocks. Recommendations suggest that garlic intended for consumption

Received for publication17 Oct. 2002. Accepted for publication 25 Aug. 2003. Use of trade names does notimply endorsement of products named or criticism of ones not mentioned. We appreciate the assistance of ones not mentioned. We appreciate the assistance
of Leigh Towill, Liv Lyons, and Nick Rotindo for performing quality evaluations. We thank Larry Hanson at ConAgra Foods, Inc., for garlic bulbs. These studies were funded in part by the Colorado State University Specialty Crops Program.

${ }^{1}$ To whom reprint requests should be addressed; e-mail gvolk@lamar.colostate.edu.

be stored at -1 to $0{ }^{\circ} \mathrm{C}, 60 \%$ to $70 \%$ relative humidity $(\mathrm{RH})$, which allows it to keep for $>9$ months (Cantwell 2002).

Kline (1990) recommends -5 to $0{ }^{\circ} \mathrm{C}$ storage temperatures for storage before consumption, but also states that the quality can deteriorate quickly once returned to ambient temperatures. For example, 'California Late' garlic stored for $>5$ months at $0^{\circ} \mathrm{C}$ and $70 \% \mathrm{RH}$ sprouts rapidly when brought to room temperature (Mann and Lewis, 1956). Mann and Minges (1958) report that the 'California Late' garlic cultivar does not bulb properly when stored at temperatures $<0{ }^{\circ} \mathrm{C}$, matures early, and often appears rough (missing outer skins and possessing external cloves). The response to storage temperatures below $0{ }^{\circ} \mathrm{C}$ has not been evaluated for most other garlic cultivars.

The physiological process of dormancy is not well understood in Allium sativum, but it is known that garlic has an innate rest period for 4 to 6 weeks after harvest, during which it does not sprout regardless of growth environment. Following this innate rest, there is a period of dormancy that is most rapidly broken by storage at 5 to $10{ }^{\circ} \mathrm{C}$ (Brewster, 1994). Once dormancy is broken, the green shoot within each clove elongates and eventually sprouts. This elongation process begins $\approx 70 \mathrm{~d}$ after harvest for garlic stored at $20{ }^{\circ} \mathrm{C}$ and $20 \%$ to $30 \%$ RH (Arguello et al., 1983). Storage conditions (length and temperature) affect the time to sprouting and clove initiation (Arguello et al., 1983; Mann and Lewis, 1956; Rahim and Fordham, 1988)

Fall planting is standard practice for garlic. Once planted, cloves sprout, then overwinter in the field and continue to grow in the early spring. Bulbs usually mature as plants senesce in midsummer. Some environments are not favorable for fall planting. The fall planting season in Colorado is often cold and snowy. Furthermore, Colorado plains winters can be extremely windy, making it difficult to retain mulch during the dry, long winters. Irrigation, while necessary, can be impractical. Although there are some expected drawbacks to spring planting, such as reduced yields (Siddique and Rabbani, 1985), it may be an alternative during years in which fall planting is impossible. For spring planting to be successful, garlic bulbs must remain viable in storage until spring (April, perhaps March)

In addition, it would be desirable for growers to be able to sell garlic for consumption during the season when fresh garlic is for the most part unavailable on the world market. To accomplish this, these bulbs must be stored from the previous year's harvest and remain edible for at least 1 month after a return to ambient temperatures.

We demonstrate that garlic bulbs can be stored at $-3{ }^{\circ} \mathrm{C}$ successfully and that cloves from these bulbs are productive when springplanted. Furthermore, we suggest that the clove quality remains high for at least 2 months after cold-stored garlic bulbs are returned to ambient temperatures. These findings increase the flexibility for garlic use year-round, since garlic is made available for both spring planting and consumption $>9$ months after harvest.

\section{Materials and Methods}

Bulbs of four garlic cultivars were provided by ConAgra Foods, Inc. (Gilroy, Calif.): 'California Early' and 'California Late' (softnecks) and 'Chinese' and 'Spanish Red' (hardnecks). The 2001 crop of garlic from ConAgra Foods, Inc., in Hanford, Calif., was cured in the field, cleaned, and kept at ambient temperatures until 5 Sept. 2001, at which time it was placed in controlled temperature storage conditions at $23{ }^{\circ} \mathrm{C}$ (range of 20 to $25^{\circ} \mathrm{C}$ and $32 \% \mathrm{RH}$ ), $15^{\circ} \mathrm{C}$ (range of 12 to $17^{\circ} \mathrm{C}$ and $35 \% \mathrm{RH}$ ), 5 ${ }^{\circ} \mathrm{C}$ (range of 3 to $7.5^{\circ} \mathrm{C}$ and $85 \% \mathrm{RH}$ ), $0{ }^{\circ} \mathrm{C}$ (range of -1.5 to $2.5^{\circ} \mathrm{C}$ and $43 \% \mathrm{RH}$ ), and $-3{ }^{\circ} \mathrm{C}$ (range of -1 to $-5.5^{\circ} \mathrm{C}$ and $76 \% \mathrm{RH}$ ). The softneck cultivars 'Inchelium Red' and 'Silverwhite' and hardneck cultivars 'Chesnok Red', 'German Porcelain', 'GSF65', 'Polish Hardneck', 'Romanian Red', 'Siberian', 'Spanish Roja' (genetically distinct from 'Spanish Red', Volk et al., unpublished), and 'Zemo' were provided by Yucca Ridge Farm, Inc. (TheGarlicStore.com; Ft. Collins, Colo.) Garlic bulbs were harvested in early August, 2001 and cured in an open-air pole barn for 4 weeks before trimming and cleaning. Bulbs were stored indoors in baskets at $25^{\circ} \mathrm{C}$ until they were placed into storage at $-3{ }^{\circ} \mathrm{C}$ on 20 Sept. 2001. For storage studies, garlic was kept in closed cardboard boxes packed lightly with crumpled newspaper.

At least five bulbs of 'California Early', 'California Late', 'Chinese', and 'Spanish Red' garlic were removed from the storage conditions bimonthly and the length of the shoot within at least 10 cloves from these bulb were measured. A percent shoot elongation 
was calculated by dividing the length of the shoot by the length of the clove and multiplying by 100 .

Bulbs were stored at room temperature until fall planting (10 Oct. 2001) or at the experimental storage conditions as listed above for spring planting on 6 Apr. 2002 (S1). Garlic bulbs planted on 26Apr. 2002 (S2) were removed from storage with the $\mathrm{S} 1$ bulbs, and then kept at $5{ }^{\circ} \mathrm{C}$ until planting ( $\left.20 \mathrm{~d}\right)$. Immediately before planting, all the bulbs of a cultivar were cracked open and uniform cloves were selected for inclusion in experiments. Sixteen cloves were planted in three replicate square plots measuring $30 \mathrm{~cm}$ on a side (in a $4 \times 4$ pattern). Plots were randomized within a region of a commercial garlic field with loam soils at Yucca Ridge Farm, Inc. Fall-planted garlic was mulched with straw $(10 \mathrm{~cm})$. In the fall, soil was amended with steer manure and plants were foliar sprayed with fish emulsion in June. The compacted straw mulch that remained after winter was left on the plots throughout the growing season. Plots were manually weeded, overhead watered for $20 \mathrm{~min}$ (50 to $100 \mathrm{~mm} \mathrm{H}_{2} \mathrm{O}$ ) daily and certified according to the Colorado Organic Certification Act. Scapes were removed when they formed. Bulbs were harvested when mature (about half of the leaves were dry) and were cured in a growth room at $27^{\circ} \mathrm{C}$ and $20 \% \mathrm{RH}$ for 3 weeks before cleaning and data collection. Circumference and bulb weights were determined for five bulbs from each plot and the number of cloves per bulb (total number of cloves) and individual clove weights (average of five representative plantable cloves) were determined for three bulbs from each plot. For each phenotypic character, comparisons among storage temperatures and

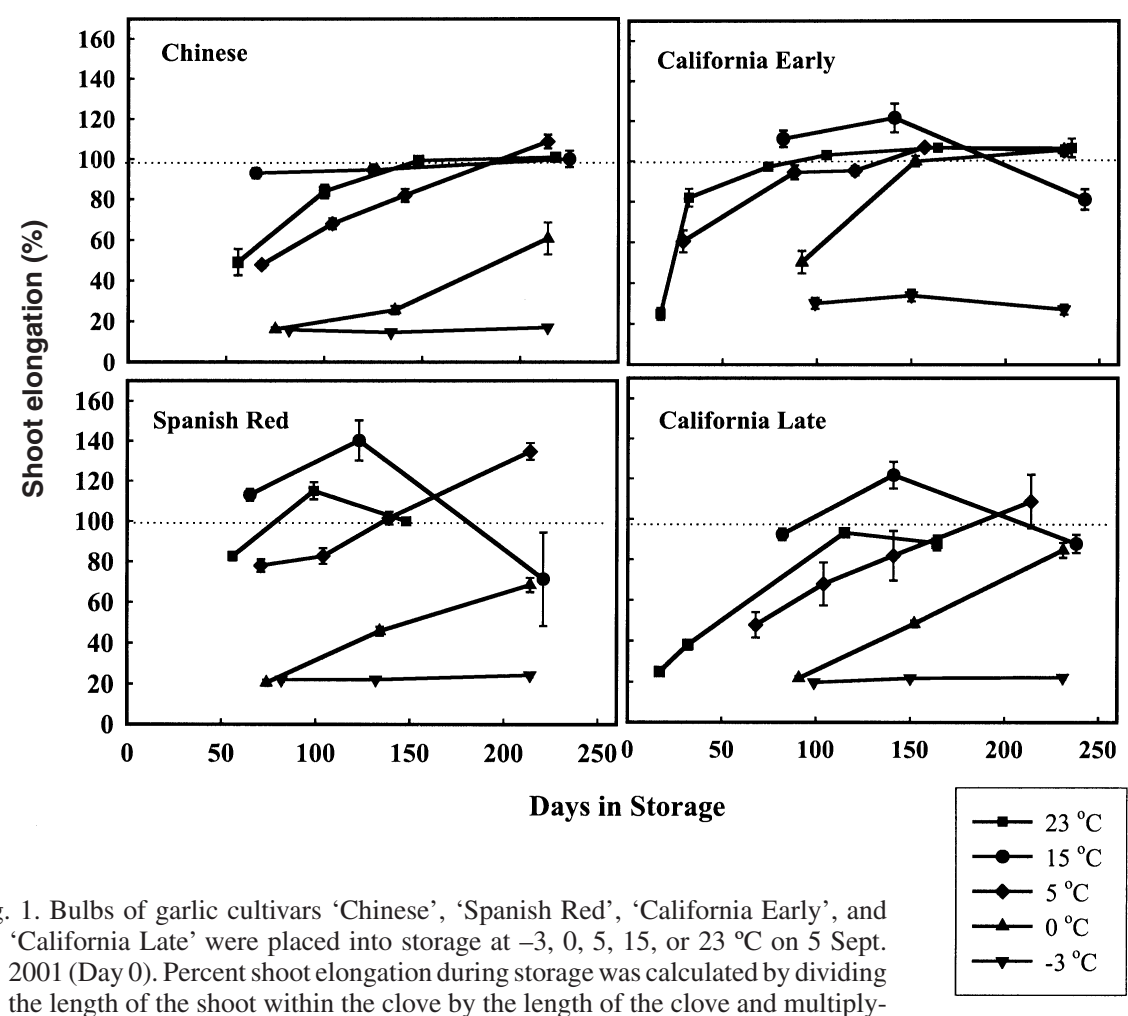
the length of the shoot within the clove by the length of the clove and multiplying by 100 . Means \pm SE of a minimum of 10 average sized cloves for each time point are shown

planting dates were made within each cultivar. ANOVA tables were generated and Tukey HSD means separation tests were performed using JMP (SAS Institute, Cary, N.C.).

Quality evaluations were performed biweekly in the homes of three independent amateur tasters using garlic bulbs that were returned to ambient temperatures after storage at 0 or $-3{ }^{\circ} \mathrm{C}$ for 7 months ('Inchelium' 0 , $-3{ }^{\circ} \mathrm{C}$; 'Siberian'-3 ${ }^{\circ} \mathrm{C}$; 'Silverwhite'-3 ${ }^{\circ} \mathrm{C}$; 'German Porcelain'-3 ${ }^{\circ} \mathrm{C}$; and 'Romanian Red' $-3^{\circ} \mathrm{C}$ ), 8 months ( 'Chesnok Red' $0,-3^{\circ} \mathrm{C}$; 'Polish Hardneck' $-3{ }^{\circ} \mathrm{C}$; 'Zemo' $0,-3{ }^{\circ} \mathrm{C}$ ), or 9 months ('Inchelium' $-3^{\circ} \mathrm{C}$; 'Siberian' $-3^{\circ} \mathrm{C}$; 'Silverwhite' $-3^{\circ} \mathrm{C}$; 'German Porcelain' $-3^{\circ} \mathrm{C}$ ). Bulbs were kept in paper bags in each home (temperatures fluctuated between 21 and $30^{\circ} \mathrm{C}$ ) between April and August 2002. The tasters were provided a chart with descriptions for the five levels of each quality characteristic (color, firmness, smell, sprouting, overall taste as well as raw and sautéed flavor intensity, heat, sweetness, and aftertaste). Due to the small size of our taste test panel and the difficulty in tasting several garlic samples at one time point, only generalizations from their records are presented.

\section{Results and Discussion}

Shootelongation during storage. In general, bulbs of the four cultivars ('Chinese', 'Spanish Red', 'California Early', and 'California Late') included in this study responded similarly to the $-3,0,5,15$, and $23^{\circ} \mathrm{C}$ storage temperatures. The dormant shoot tip represented $20 \%$ of the clove (thus, $0 \%$ elongation was never observed). Initially, shoots showed no sign of elongation within bulbs. Shoot elongation occurred most quickly at 15 and $23^{\circ} \mathrm{C}$, followed by $5^{\circ} \mathrm{C}$ (Fig 1). 'California Late' and 'Spanish Red' bulbs stored at $23{ }^{\circ} \mathrm{C}$ became severely dehydrated and unmarketable after $150 \mathrm{~d}$ in storage. Bulbs in the $0{ }^{\circ} \mathrm{C}$ storage temperature did not show significant elongation until after $70 \mathrm{~d}$ in storage, at which time shoots elongated at a rate that was specific to each cultivar. Although shoots showed no sign of elongation within the cloves after more than $200 \mathrm{~d}$ of storage at $-3{ }^{\circ} \mathrm{C}$, the cloves remained viable, as was demonstrated in the spring planting field trials. In many cases at 5,15 , and $23^{\circ} \mathrm{C}$ storage conditions, shoots elongated to the tip of the clove, but did not protrude from the clove in storage conditions.

Field studies. Garlic cultivars can be stored at 0 or $-3{ }^{\circ} \mathrm{C}$ and produce bulbs under Front Range Colorado conditions when planted in the spring (Table 1). Compared to fall plantings, there is a cost to spring planting for some cultivars. The degree of response was cultivar dependent. In general, the number of cloves per bulb was the least responsive character, with significant differences observed in half of the garlic cultivars.

Although yields were reduced, these data indicate that spring planting is possible in Colorado (despite the fact that the summer of 2002 was unusually hot and dry). The 6 Apr. planting date was rather late for spring planting, and yields probably would have been higher if planted in March.

Garlic for the S2 planting was kept at $5^{\circ} \mathrm{C}$ until planting after it was removed from cold storage at the time of the S1 planting. We chose to remove those bulbs from storage at 0 or -3 ${ }^{\circ} \mathrm{C}$ at the earlier planting date and keep them at $5{ }^{\circ} \mathrm{C}$ for $20 \mathrm{~d}$ to increase the probability of a successful harvest from late-spring planted garlic. There are several reports of increased bulb size when bulbs were kept at $5{ }^{\circ} \mathrm{C}$ for 30 to $60 \mathrm{~d}$ before planting (Bandara et al., 2000; Rahim and Fordham, 1988; Siddique and Rabbani, 1985). Future studies are needed to determine the optimum $5{ }^{\circ} \mathrm{C}$ storage duration for bulbs removed from 0 and $-3{ }^{\circ} \mathrm{C}$ storage.

The yields of $\mathrm{S} 1$ planted bulbs were compared within each cultivar to determine whether 0 or $-3{ }^{\circ} \mathrm{C}$ storage temperatures were preferable. As shown in Table 1, 'Polish Hardneck' and 'California Early' had larger bulbs when stored at $-3{ }^{\circ} \mathrm{C}$. 'Chesnok Red', 'Siberian', and 'California Early' also had more cloves per bulb when stored at $-3{ }^{\circ} \mathrm{C}$ until the $\mathrm{S} 1$ planting date.

While most cultivars did form cloves within bulbs, the 'Spanish Red' and 'Polish Hardneck' were sensitive to storage at low temperatures and formed rounds instead of cloves when planted in the spring (Table 1). The fall-planted 'Spanish Red' cultivar also exhibited roughness that included loose papers (50\% of bulbs) and side clove formation (100\% of bulbs). This garlic cultivar may be particularly responsive to storage temperatures and harvest date. Roughness occurred in some cultivars planted in the spring. Side cloves formed in bulbs of 'California Early' ( $0 \%$ to $20 \%$ of the bulbs per plot), 'California Late' (50\% to $90 \%$ of the bulbs per plot) and 'Chinese' (27\% to $60 \%$ of

HortScience Vol. 39(3) JunE 2004 
Table 1. Harvest data are presented for fourteen garlic cultivars that were fall planted, early spring planted (S1) or late spring planted (S2) after storage at $-3,0$, or $5{ }^{\circ} \mathrm{C}$. Means and significant differences within each cultivar were determined by ANOVA analyses. Tukey HSD mean separation tests were performed where significant differences were detected $(P<0.01)$.

\begin{tabular}{|c|c|c|c|c|c|c|c|c|c|c|c|c|c|c|}
\hline & \multicolumn{14}{|c|}{ Garlic variety } \\
\hline & $\begin{array}{c}\text { Spanish } \\
\text { Red }\end{array}$ & Chinese & $\begin{array}{c}\text { Chesnok } \\
\text { Red }\end{array}$ & $\begin{array}{c}\text { German } \\
\text { Porcelain }\end{array}$ & GSF65 & $\begin{array}{c}\text { Polish } \\
\text { Hardneck }\end{array}$ & $\begin{array}{l}\text { Romanian } \\
\text { Red }\end{array}$ & Siberian & $\begin{array}{c}\text { Spanish } \\
\text { Roja }\end{array}$ & \multicolumn{5}{|c|}{ California California Inchelium } \\
\hline \multicolumn{15}{|c|}{ Bulb weight (g) } \\
\hline$-3^{\circ} \mathrm{C}-\mathrm{S} 1$ & & $14.1 \mathrm{ab}$ & $19.4^{\mathrm{Ns}}$ & $24.1 \mathrm{~b}$ & $24.0 \mathrm{~b}$ & $29.2 \mathrm{a}$ & $19.0^{\text {vs }}$ & $19.4 \mathrm{~b}$ & $14.5 \mathrm{~b}$ & $16.1 \mathrm{ab}$ & $27.6 \mathrm{a}$ & $16.6 \mathrm{ab}$ & $18.5 \mathrm{~b}$ & $18.7 \mathrm{~b}$ \\
\hline$-3^{\circ} \mathrm{C}-\mathrm{S} 2$ & & $10.6 \mathrm{~b}$ & $20.6^{\mathrm{Ns}}$ & $13.7 \mathrm{c}$ & $14.5 \mathrm{~b}$ & $20.9 \mathrm{~b}$ & & & $13.0 \mathrm{~b}$ & $13.6 \mathrm{~b}$ & $24.7 \mathrm{ab}$ & $8.8 \mathrm{c}$ & $23.3 \mathrm{~b}$ & \\
\hline $0^{\circ} \mathrm{C}-\mathrm{S} 1$ & $16.4 \mathrm{~b}$ & $13.9 \mathrm{ab}$ & & & & & & & $14.5 \mathrm{~b}$ & $15.4 \mathrm{~b}$ & $18.8 \mathrm{~b}$ & $13.6 \mathrm{bc}$ & $18.5 \mathrm{~b}$ & \\
\hline $0{ }^{\circ} \mathrm{C}-\mathrm{S} 2$ & $12.5 \mathrm{~b}$ & $10.2 \mathrm{~b}$ & & & & & & & & & $11.7 \mathrm{c}$ & $11.8 \mathrm{bc}$ & & \\
\hline \multicolumn{15}{|c|}{ Circumference $(\mathrm{cm})$} \\
\hline Fall & $13.7 \mathrm{a}$ & $11.1 \mathrm{a}$ & $12.5^{\mathrm{Ns}}$ & $16.3 \mathrm{a}$ & $14.0 \mathrm{a}$ & & $13.3 \mathrm{a}$ & $16.9 \mathrm{a}$ & $14.6 \mathrm{a}$ & $11.67 \mathrm{a}$ & $13.3 \mathrm{ab}$ & $11.8 \mathrm{a}$ & $17.7 \mathrm{a}$ & $12.8^{\mathrm{vs}}$ \\
\hline$-3^{\circ} \mathrm{C}-\mathrm{S} 1$ & & $10.2 \mathrm{ab}$ & $11.5^{\mathrm{Ns}}$ & $12.3 \mathrm{~b}$ & $12.4 \mathrm{a}$ & $13.0 \mathrm{a}$ & $11.1 \mathrm{~b}$ & $11.9 \mathrm{~b}$ & $10.6 \mathrm{~b}$ & $10.5 \mathrm{ab}$ & $13.8 \mathrm{a}$ & $11.0 \mathrm{ab}$ & $11.9 \mathrm{~b}$ & $11.8^{\mathrm{Ns}}$ \\
\hline$-3{ }^{\circ} \mathrm{C}-\mathrm{S} 2$ & & $9.7 \mathrm{ab}$ & $11.6^{\mathrm{Ns}}$ & $9.8 \mathrm{c}$ & $10.7 \mathrm{~b}$ & $11.6 \mathrm{~b}$ & & & $9.9 \mathrm{~b}$ & $9.7 \mathrm{~b}$ & $13.5 \mathrm{ab}$ & $8.6 \mathrm{c}$ & $12.7 \mathrm{~b}$ & \\
\hline $0{ }^{\circ} \mathrm{C}-\mathrm{S} 1$ & $10.4 \mathrm{~b}$ & $10.6 \mathrm{ab}$ & $11.2^{\mathrm{Ns}}$ & & & $11.1 \mathrm{~b}$ & $12.0 \mathrm{~b}$ & $10.3 \mathrm{~b}$ & $10.6 \mathrm{ab}$ & $12.0 \mathrm{~b}$ & $10.1 \mathrm{~b}$ & $12.2 \mathrm{~b}$ & & \\
\hline $0{ }^{\circ} \mathrm{C}-\mathrm{S} 2$ & $9.4 \mathrm{~b}$ & $9.2 \mathrm{~b}$ & & & & & & & & & & $9.8 \mathrm{c}$ & $9.9 \mathrm{bc}$ & \\
\hline $5^{\circ} \mathrm{C}-\mathrm{S} 1$ & & $9.9 \mathrm{ab}$ & & & & & & & & & & & & \\
\hline $0{ }^{\circ} \mathrm{C}-\mathrm{S} 1$ & $1.0 \mathrm{~b}$ & $9.3^{\mathrm{Ns}}$ & $10.4 \mathrm{a}$ & & & $2.7^{\mathrm{Ns}}$ & & $4.3 \mathrm{~b}$ & $7.2^{\mathrm{ss}}$ & $2.7 \mathrm{~b}$ & $6.1 \mathrm{~b}$ & $12.2 \mathrm{~b}$ & $9.6^{\mathrm{Ns}}$ & \\
\hline $0^{\circ} \mathrm{C}-\mathrm{S} 2$ & $1.0 \mathrm{~b}$ & $6.7^{\mathrm{Ns}}$ & & & & & & & & & $6.4 \mathrm{~b}$ & $12.3 \mathrm{~b}$ & & \\
\hline $5^{\circ} \mathrm{C}-\mathrm{S} 1$ & & $6.3^{\mathrm{ss}}$ & & & & & & & & & & & & \\
\hline $5^{\circ} \mathrm{C}-\mathrm{S} 2$ & & $6.9^{\mathrm{Ns}}$ & & & & & & & & & & & & \\
\hline \multicolumn{15}{|c|}{ Clove weight (g) } \\
\hline Fall & $7.4 \mathrm{~b}$ & $2.2 \mathrm{a}$ & $3.0^{\mathrm{vs}}$ & $11.5 \mathrm{a}$ & $5.1 \mathrm{a}$ & & $1.9 \mathrm{~b}$ & $10.8 \mathrm{a}$ & $4.2 \mathrm{a}$ & $4.8^{\mathrm{NS}}$ & $2.5^{\mathrm{Ns}}$ & $1.6 \mathrm{a}$ & $6.3 \mathrm{a}$ & $2.0 \mathrm{a}$ \\
\hline$-3^{\circ} \mathrm{C}-\mathrm{S} 1$ & & $1.5 \mathrm{ab}$ & $3.0^{\mathrm{Ns}}$ & $6.5 \mathrm{~b}$ & $3.0 \mathrm{~b}$ & $12.0^{\mathrm{Ns}}$ & $5.2 \mathrm{a}$ & $2.7 \mathrm{c}$ & $1.5 \mathrm{~b}$ & $5.2^{\mathrm{Ns}}$ & $2.6^{\mathrm{Ns}}$ & $1.5 \mathrm{a}$ & $2.0 \mathrm{~b}$ & $1.4 \mathrm{~b}$ \\
\hline$-3^{\circ} \mathrm{C}-\mathrm{S} 2$ & & $1.1 \mathrm{~b}$ & $2.4^{\mathrm{Ns}}$ & $4.8 \mathrm{~b}$ & $1.9 \mathrm{~b}$ & $7.3^{\mathrm{Ns}}$ & & & $1.8 \mathrm{~b}$ & $3.8^{\mathrm{Ns}}$ & $2.3^{\mathrm{Ns}}$ & $0.9 \mathrm{~b}$ & $2.1 \mathrm{~b}$ & \\
\hline $0^{\circ} \mathrm{C}-\mathrm{S} 1$ & $18.2 \mathrm{a}$ & $1.8 \mathrm{ab}$ & $2.1^{\mathrm{Ns}}$ & & & $9.2^{\mathrm{vs}}$ & & $4.6 \mathrm{~b}$ & $2.1 \mathrm{~b}$ & $5.7^{\mathrm{Ns}}$ & $3.6^{\mathrm{Ns}}$ & $1.2 \mathrm{ab}$ & $1.9 \mathrm{~b}$ & \\
\hline $0^{\circ} \mathrm{C}-\mathrm{S} 2$ & $13.4 \mathrm{ab}$ & $1.9 \mathrm{ab}$ & & & & & & & & & $3.0^{\mathrm{Ns}}$ & $1.1 \mathrm{ab}$ & & \\
\hline $5^{\circ} \mathrm{C}-\mathrm{S} 1$ & & $2.2 \mathrm{a}$ & & & & & & & & & & & & \\
\hline $5^{\circ} \mathrm{C}-\mathrm{S} 2$ & & $1.4 \mathrm{ab}$ & & & & & & & & & & & & \\
\hline
\end{tabular}

the bulbs per plot) cultivars stored at $0{ }^{\circ} \mathrm{C}$ and this roughness was not observed when bulbs of these cultivars were stored at $-3{ }^{\circ} \mathrm{C}$. While many cultivars exhibited no signs of roughness, some garlic bulbs stored at $-3{ }^{\circ} \mathrm{C}$ and planted in the spring had either loose papers or side clove formation ('Spanish Roja', 0 to $45 \%$ of the bulbs per plot; 'Inchelium Red', 0 to $75 \%$ of the bulbs per plot). Bulb roughness responses are dependent upon cultivar and storage temperature.

The results obtained in these studies could differ if repeated for another season and additional storage tests should be conducted before recommendations are made to growers.

Consumption after storage. Qualitative evaluations were performed on garlic bulbs of several cultivars that were removed from storage at 0 or $-3{ }^{\circ} \mathrm{C}$ after 7,8 , or 9 months. The three tasting-panel members agreed that 'Inchelium Red' $\left(-3^{\circ} \mathrm{C}\right)$, 'Siberian' $\left(-3^{\circ} \mathrm{C}\right)$, and 'Silverwhite' $\left(-3^{\circ} \mathrm{C}\right)$ retained high quality characteristics (firmness, flavor, color) for $>3$ months at room temperature. 'German Porcelain' $\left(-3{ }^{\circ} \mathrm{C}\right)$ and 'Romanian Red' $\left(-3^{\circ} \mathrm{C}\right)$, which were initially softer than the other cultivars when placed into cold storage, remained edible for only 2 months at room temperature storage. There were no differences observed in bulb quality among bulbs removed from storage after 6 or 8 months at $-3{ }^{\circ} \mathrm{C}$. In addition, the flavors of stored garlics did not change noticeably at room temperature until the garlic began to discolor and shrivel. Bulbs of 'Chesnok Red', 'Zemo', and 'Inchelium Red' stored at $0{ }^{\circ} \mathrm{C}$ tended to be softer, more aromatic and had a shorter shelflife than those stored at $-3{ }^{\circ} \mathrm{C}$.

\section{Conclusions}

Both hardneck and softneck garlic bulbs can be stored at $-3^{\circ} \mathrm{C}$ and spring-planted under Colorado Front Range growing conditions. Although yields were lower, spring planting provides an alternative to the traditional fall planting, and the problems associated with mulching and irrigation during the winter can be minimized.

\section{Literature Cited}

Arguello, J.A., R. Bottini, R. Luna, G.A. de Bottini, and R.W. Racca. 1983. Dormancy in garlic ( $\mathrm{Al}$ lium sativum L.) cv. Rosado Paraguayo I. Levels of growth substances in "seed cloves" under storage. Plant Cell Physiol. 24(8):1559-1563.

Bandara, M.S., K. Krieger, A.E. Slinkard, and K.K. Tanino. 2000. Pre-plant chilling requirements for cloving of spring-planted garlic. Can J. Plant Sci. 80:379-384.

Brewster, J.L. 1994. Onions and other vegetable alliums. CAB Intl., Wallingford, U.K.

Cantwell, M. 2002. In: K.C. Gross, C.Y Wang, and M. Saltveit. 2002. The commercial storage of fruits, vegetables, and florist and nursery crops. An Adobe Acrobat pdf of a draft version of the forthcoming revision to USDA-ARS Hndbk.
66. 8 Nov. 2002. <http://www.ba.ars.usda gov/hb66/index.html>.

Chakraverty, A., A.S. Mujumdar, G.S.V. Raghavan, H.S. Ramaswamy. 2003. Handbook of postharvest technology. Marcel Dekker, New York.

Kline, R.A. 1990. Garlic. Dept. Veg. Crops and the Garlic Seed Found. N.Y. State VC Rpt. 387, Cornell Univ., Ithaca, N.Y.

Mann, L.K. and D.A. Lewis. 1956. Rest and dormancy in garlic. Hilgardia 8:161-189.

Mann, L.K. and P.A. Minges. 1958. Growth and bulbing of garlic (Allium sativum L.) in response to storage temperature of planting stocks, day length, and planting date. Hilgardia 27:385-419.

Pooler, M.R. and P.W. Simon. 1993. Characterization and classification of isozyme and morphological variation in a diverse collection of garlic clones. Euphytica 68:121-130.

Rahim, M.A. and R. Fordham. 1988. Effect of storage temperature on the initiation and development of garlic cloves (Allium sativum L.). Sci. Hort. of garlic co

Rosen, C., R. Becker, V. Fritz, B. Hutchison, J. Percich, C. Tong, and J. Wright. 1999. Growing garlic in Minnesota. Univ. Minn. Ext. Serv. Bul. WW-07317.

Siddique, M.A. and M.G. Rabbani. 1985. Growth and bulbing of garlic in response to low temperature treatment of bulb and planting date. Bangladesh J. Bot. 14:41-46.

Warade, S.D. and K.G. Shinde. 1998. Garlic, p. 397-413. In: D.K. Salunkhe and S.S. Kadam (eds.). Handbook of vegetable science and technology. Marcel Dekker, New York. 